\title{
Adsorption Kinetics of 4-Amino-5-Phenyl-4H-1, 2, 4- Triazole-3-Thiol on Mild Steel Surface
}

\author{
Anees A. Khadom, ${ }^{*}$ Ahmed Y. Musa, Abdul Amir H. Kadhum, Abu Bakar \\ Mohamad, Mohd Sobri Takriff
}

Department of Chemical and Process Engineering, Faculty of Engineering and Built Environment, Universiti Kebangsaan Malaysia, Bangi, 43600, Selangor, Malaysia

\begin{abstract}
The adsorption of 4-amino-5-phenyl-4H-1, 2, 4-triazole-3-thiol (APTT) as a corrosion inhibitor on mild steel surface in hydrochloric acid $(\mathrm{HCl})$ solution was studied using the weight loss technique. The surface coverage with the adsorbed APTT was used to calculate the free energy of adsorption, $\Delta G_{\text {ads }}^{0}$, of APTT using Bockris-Swinkels isotherm. The dependence of free energy of adsorption, $\Delta \mathrm{G}^{\mathrm{o}}$ ads, on the surface coverage, $\theta$, is ascribed to the surface heterogeneity of the adsorbent. The effect of APTT was discussed from the adsorption model viewpoint. The adsorption of APTT molecules on the surface occurs without modifying the kinetic of corrosion process.
\end{abstract}

Keywords: corrosion, inhibitor layers, mild steel, adsorption.

\section{Introduction}

Acid solution is widely used in industry as acid cleaning, acid descaling, acid pickling and oil well acidizing. In these acid solutions the corrosion inhibitors are required in order to restrain the acid erosion of metallic materials $[1,2]$.

Inhibitor adsorption on metal surface plays a very important role in the development and understanding of electrochemical processes viz: double layer, electrokinetics, corrosion and its inhibition, electroorganic synthesis on metal surface, and the concept related to surface process on metals and alloys, and catalysis. The mechanism of adsorption of the inhibitor molecules on the metal surface is clearly of importance, since the degree of protection of the metal is a function of adsorption, and a detailed mechanism for inhibition of the metal and the development of new corrosion inhibitors for metals are not possible without

\footnotetext{
* Corresponding author. E-mail address: aneesdr@gmail.com
} 
understanding the adsorption process $[3,4]$. In different media, for a given metal, the efficiency of the inhibitor depends on the stability of the formed complex, and the inhibitor molecules should have centers, which are capable of forming electrostatic attraction with the metal surface via an electron transfer. Generally, a strong co-ordination bond causes higher inhibition efficiency; the inhibition increases in the sequence $\mathrm{O}<\mathrm{N}<\mathrm{S}<\mathrm{P}[5,6]$.

A number of studies have been carried out in the determination of the adsorption of various compounds at the electrode/solution interface [7-10]. The type of interaction of the inhibitor on the metal surface during corrosion has been deduced from its adsorption characteristics by several authors [3, 11-16].

In this work, a 4-amino-5-phenyl-4H-1, 2, 4-trizole-3-thiol (APTT) was investigated as corrosion inhibitor for mild steel in $1 \mathrm{M}$ hydrochloric acid $(\mathrm{HCl})$ as corrosive solution, at $30^{\circ} \mathrm{C}$. This molecule contains one co-ordinate $(=\mathrm{N}-$, $\left.-\mathrm{NH}_{2}\right)$ and one covalent $(-\mathrm{S}-\mathrm{H})$ groups which can form a protecting film on the surface of mild steel. Weight loss methods were used in this investigation to predict the corrosion inhibition efficiency of this agent on the surface of mild steel sample.

\section{Experimental}

The working electrode employed in this work has been made from mild steel as cylindrical rods. Weight loss corrosion inhibition tests were performed using cylindrical coupons measuring $0.9 \mathrm{~cm}$ in diameter and $1.1 \mathrm{~cm}$ in height, exposing about $3.11 \mathrm{~cm}^{2}$ effective surface area. These coupons were first mechanically polished using SiC paper in successive grades from 200 to 1500 , washed with deionized water thoroughly, degreased with absolute ethanol and dried. The

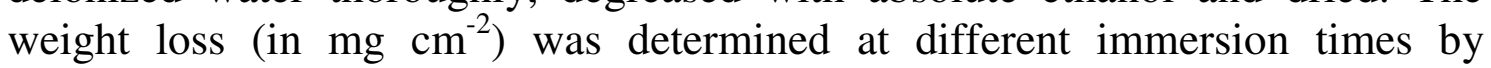
weighing the cleaned samples before and after hanging the coupon into $150 \mathrm{~mL}$ of the corrosive solution, namely $1 \mathrm{M} \mathrm{HCl}$ (in open air) in the absence and presence of various ATTP concentrations at $30{ }^{\circ} \mathrm{C}$. After that, elapsed the cleaning procedure consisting on wiping the coupons with a paper tissue and washing them with distilled water and methanol, dried at room temperature until time of use.

\section{Results and discussion}

The variation of the weight loss $\left(\mathrm{mg} \mathrm{cm}^{-2}\right)$ for mild steel electrode in $1 \mathrm{M} \mathrm{HCl}$ at $30{ }^{\circ} \mathrm{C}$ with the immersion time, in solutions without and with various concentrations (from $5 \times 10^{-5}$ to $80 \times 10^{-5} \mathrm{M}$ ) of APTT at $30{ }^{\circ} \mathrm{C}$, is presented in Fig. 1. The slope of each line $\left(\mathrm{mg} \mathrm{cm}^{-2} \mathrm{~h}^{-1}\right)$ represents the corrosion rate of mild steel at the specified conditions. Addition of APTT inhibitor to the acidic solution retards the weight loss of mild steel. This is clearly seen from the decrease in weight loss, corresponding to a noticeable decrease in the slope of each line (mg $\mathrm{cm}^{-2} \mathrm{~h}^{-1}$ ), with increase in the inhibitor concentration. This trend is due to the adsorption and surface coverage increases with the increase in APTT concentration; thus the surface is separated from the medium $[17,18]$. 


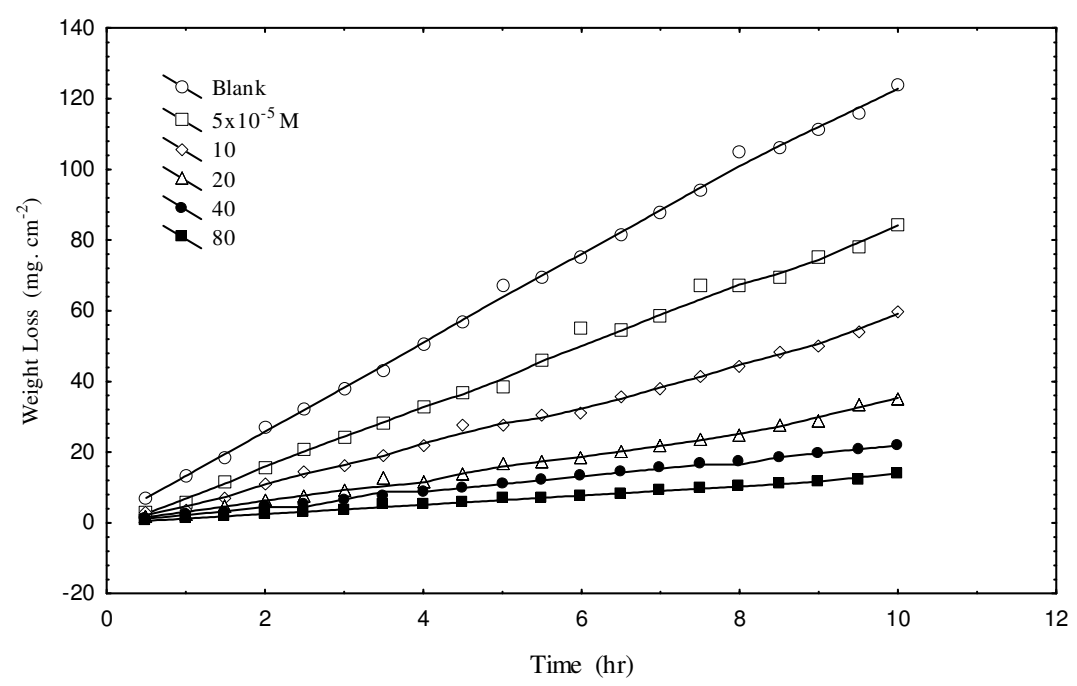

Figure 1. Variation of weight loss data (in $\mathrm{mg} \mathrm{cm}^{-2}$ ) with immersion time for mild steel in $1 \mathrm{M} \mathrm{HCl}$ solution without and with APTT at $30^{\circ} \mathrm{C}$.

The inhibition efficiency (IE\%) values were calculated at $30{ }^{\circ} \mathrm{C}$, using equation (1) $[19,20]$.

$$
I E \%=\frac{R_{\text {uninibit }}-R_{\text {inhibit }}}{R_{\text {uninhibit }}} \times 100
$$

where $R_{\text {uninhibit }}$ and $R_{\text {inhibit }}$ are the corrosion rates of specimens without and with the inhibitor. Fig. 2 shows the variation of inhibitor efficiencies (IE\%) and the corrosion rate values as a function of concentration of the inhibitor $(\ln C)$. It is obvious from the data of Fig. 2 that the inhibition efficiency generally increases with an increase in inhibitor concentration. Table 1 collects the values of inhibitor efficiency and corrosion rate $\left(\mathrm{mg} . \mathrm{cm}^{-2} \cdot \mathrm{hr}^{-1}\right)$ obtained from weight loss measurements for different concentrations of the inhibitor in $1 \mathrm{M} \mathrm{HCl}$. Fig. 2 and Table 1 indicate that the addition of APTT to the electrolyte (1 $\mathrm{M} \mathrm{HCl}$ solutions) decreased the corrosion rate of the metal, signifying the inhibition of the mild steel corrosion in the $\mathrm{HCl}$ solution, with the maximum $89.28 \%$ protection efficiency.

Table 1. Variation of corrosion rate and \% protection (IE\%) with APTT concentration in $1 \mathrm{M} \mathrm{HCl}$ solution.

\begin{tabular}{ccc}
\hline $\mathrm{C}(\mathrm{M}) 10^{-5}$ & Corrosion rate $\left(\mathrm{mg} \cdot \mathrm{cm}^{-2} \cdot \mathrm{hr}^{-1}\right)$ & IE\% \\
\hline 0 & 12.356 & 0 \\
5 & 8.592 & 30.46 \\
10 & 5.773 & 53.27 \\
20 & 3.364 & 72.77 \\
40 & 2.188 & 82.29 \\
80 & 1.324 & 89.28 \\
\hline
\end{tabular}




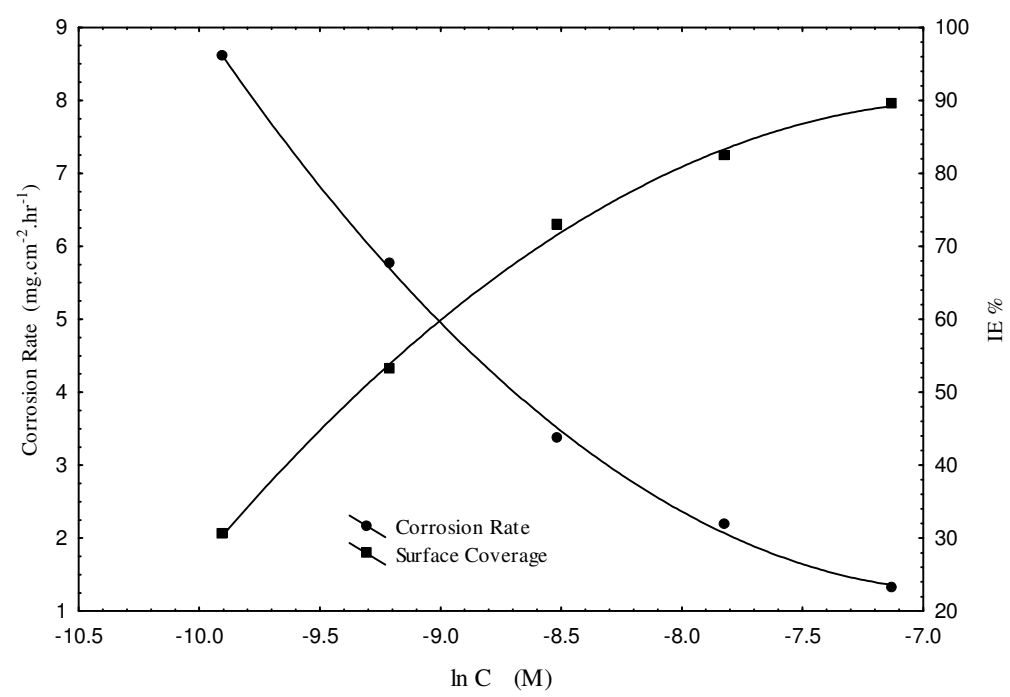

Figure 2. Variation of the corrosion rate and surface coverage with APTT concentration in $1 \mathrm{M} \mathrm{HCl}$ at $30^{\circ} \mathrm{C}$.

For organic corrosion inhibitor acting via adsorption mode, as shown in Figs. 3 and 4, the apparent corrosion rate of the inhibited metal sample is proportional to the ratio of the surface covered by the inhibitor, $\theta$, being that not covered denoted by $(1-\theta)$ [21,22]. Consequently, the surface coverage $\theta$, at the electrode was estimated on the basis of a relative decrease in the rate of corrosion of mild steel sample $\left(\mathrm{mg} \mathrm{cm}^{-2} \mathrm{~h}^{-1}\right)$ in the electrolytes, as described by equation 2 :

$$
\theta=1-\frac{R_{\text {inhibt }}}{R_{\text {uninhibit }}}
$$

where $\theta$ is the electrode coverage, and $\mathrm{R}_{\text {uninhibit }}$ and $\mathrm{R}_{\text {inhibit }}$ are given as in equation (1). The extent of retardation of the corrosion rate $\left(\mathrm{mg} . \mathrm{cm}^{-2} \cdot \mathrm{hr}^{-1}\right)$ (Fig. 3) depends on the degree of the surface coverage, $\theta$, of the metal with the adsorbate. The surface of the electrode in aqueous solution is considered to be covered with water dipoles, and for adsorption of organic molecules to occur, these water dipoles must be replaced by organic molecules in a reaction that is formally equivalent to a chemical reaction as follows [23]:

$$
n \mathrm{H}_{2} \mathrm{O}_{\text {electrode }}+\text { Organic }_{\text {solution }} \Leftrightarrow \text { Organic }_{\text {electrode }}+n \mathrm{H}_{2} \mathrm{O}_{\text {solution }}
$$

The thermodynamics of the substitution process depends on the number of water molecules $(n)$ removed by the organic molecules. The values of the apparent free energy change, $\Delta \mathrm{G}^{\mathrm{o}}{ }_{\mathrm{ads}}$, for the adsorption process can be evaluated from $\theta$ values with the help of Bockris-Swinkels equation $[12,24]$, which is written in the form: 


$$
\Delta G_{a d s}^{o}=-2.303 R T \log \left[\frac{55.5 \theta}{C_{o}(1-\theta)^{n}} \frac{[\theta+(1-\theta) n]^{n-1}}{n^{n}}\right]
$$

where $\theta$ is the surface coverage, $\mathrm{n}$, the number of water molecules being replaced, and $\mathrm{C}_{\mathrm{o}}$, the concentration of the organic compound in the bulk solution.

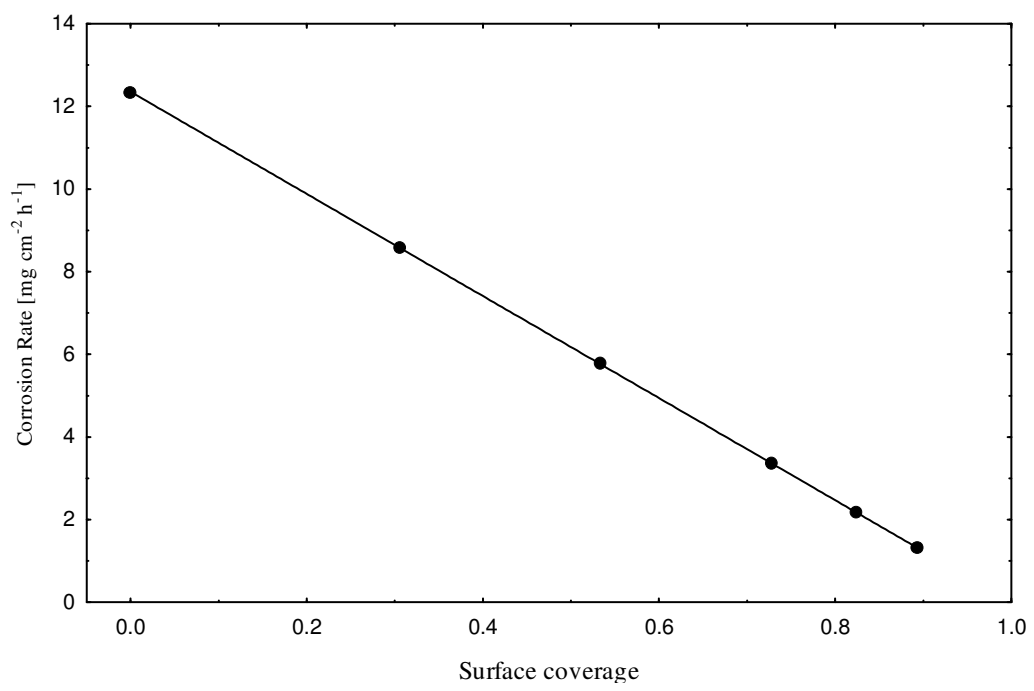

Figure 3. Variation of the corrosion rate $\left(\mathrm{mg} \mathrm{cm}^{-2} \mathrm{~h}^{-1}\right)$ of mild steel coupon with surface coverage of APTT in $1 \mathrm{M} \mathrm{HCl}$ solution in $30^{\circ} \mathrm{C}$.

By considering $\mathrm{n}=1$, then equation (4) can be simplified in the form given in equation (5). Based on the substitutional adsorption process for the space filling models [24,25] of adsorption of organic molecules on the electrode surface, for adsorption of APTT on mild steel surface, the values of $\Delta \mathrm{G}_{\text {ads }}^{\mathrm{a}}$ for the adsorption process were calculated from $\theta$ values using equation (5).

Bockris and Reddy [23] had pointed out that for simplified analysis, when $n=1$ (as in equation 5) yields qualitatively the same type of behavior as does the complicated analysis, when $n>1$ (as in equation 4 ).

$$
\Delta G_{a d s}^{o}=-2.303 R T \log \left[\frac{55.5 \theta}{C_{o}(1-\theta)}\right]
$$

The dependence of $\Delta \mathrm{G}^{\mathrm{o}}$ ads of APTT with $\theta$ in $1 \mathrm{M} \mathrm{HCl}$ solutions is given in Fig. 4. In this figure, the negative $\Delta \mathrm{G}^{\mathrm{o}}$ ads increased with the increase of $\theta$.

As shown in Fig. 4, the adsorption behavior of APTT on the mild steel surface for $n=1$ and $n=3(n>1)$ is very similar: the curves for APTT for the two cases are similar in shape. The $\Delta \mathrm{G}_{\text {ads }}^{\mathrm{a}}$ dependences on the coverage of the metal by APTT, obtained for the simple case, $n=1$, resemble qualitatively those obtained for the complex case, $n=3$. This is in agreement with the reported by Bockris and Reddy [23].

The variation of negative $\Delta \mathrm{G}^{0}$ ads of the adsorbate on $\theta$ can be rationalized as due to the surface heterogeneity of the adsorbent. Unlike a liquid electrode, the surface of a solid electrode can be heterogeneous with respect to the adsorption energy, due to the fact that the free surface energy depends on the orientation of 
the metal crystals, and concentration of flaws (such as dislocations, vacancies, micro distortions of crystal lattice, etc.) at the interface [25,26]. Consequently, all sites are not equivalent on the surface of a solid electrode due to heterogeneity; there will be a hierarchy of sites and a hierarchy of adsorption energies as observed experimentally and can be realized clearly in Fig. 4.

The negative values of $\Delta \mathrm{G}^{\mathrm{o}}$ ads indicate the spontaneous adsorption of APTT molecules and are usually characteristic of strong interaction with the metal surface. Generally, values of $\Delta G_{a d s}^{o}$ up to $-20 \mathrm{~kJ}^{\circ} \mathrm{mol}^{-1}$ are consistent with electrostatic interaction between the charged molecules and the charged metal (physisorption), while those around $-40 \mathrm{~kJ} \mathrm{~mol}^{-1}$ or higher are associated with chemisorptions as a result of sharing or transfer of electrons from the organic molecules to the metal surface, to form a coordinate type of bond [27,28]. Other researchers suggested that the range of $\Delta G_{\text {ads }}^{o}$ of chemical adsorption processes for organic inhibitor in aqueous media lies between -21 to $-42 \mathrm{~kJ} \cdot \mathrm{mol}^{-1}$ [29].

For the present study the mean $\Delta \mathrm{G}_{\text {ads }}^{\mathrm{o}}$ values of $-33.688 \mathrm{~kJ} \mathrm{~mol}^{-1}$, for, $\mathrm{n}=1$, and $36.734 \mathrm{~kJ} \mathrm{~mol}^{-1}$, for, $\mathrm{n}=3$, for $1 \mathrm{M} \mathrm{HCl}$ are consistent within the range of chemical adsorption.

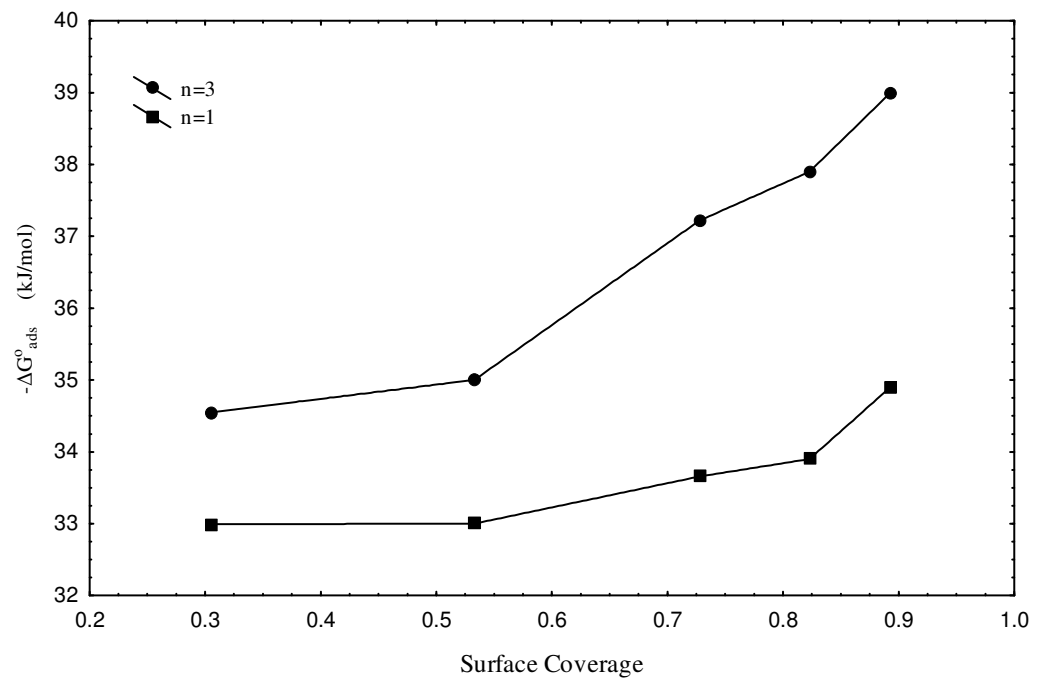

Figure 4. $\Delta \mathrm{G}_{\text {ads }}^{\mathrm{o}}$ for APTT on mild steel as a function of surface coverage in $1 \mathrm{M} \mathrm{HCl}$ solution at $30^{\circ} \mathrm{C}$.

In this study, the weight of mild steel at time $t$ is designated as $\mathrm{W}_{\mathrm{L}}$, which is calculated from the loss of mass of mild steel in $1 \mathrm{M} \mathrm{HCl}$ at regular time intervals. The kinetics of mild steel corrosion in $\mathrm{HCl}$ and $\mathrm{HCl}$-adsorbate systems were investigated. The plots of logarithm of $\mathrm{W}_{\mathrm{L}}$ (weight at time $\mathrm{t}$ ) versus time in electrolytes and electrolytes-adsorbate systems are reported in Fig. 5. The resulting lines in the absence and presence of the adsorbate (APTT) confirm a deviation from first-order reaction kinetics in $1 \mathrm{M} \mathrm{HCl}$ solution.

The similarity of the curves in the presence and absence of the adsorbate suggests that its adsorption does not change the kinetics of the hydrogen evolution reaction, though it significantly reduces its rate, as seen in Figs. 2 and 3. This also confirms that the adsorbate inhibits via a blocking adsorption mechanism. 
The corrosion of iron in $\mathrm{HCl}$ solutions is an electrochemical process, which is largely accomplished by the action of a network of short-circuited electrolytic cells on the metal surface. Iron ions go into solution at the anodes of these cells in an amount chemically equivalent to the reaction at the cathodes. The anodic reaction of iron in $\mathrm{HCl}$ solution is,

$$
\mathrm{Fe} \rightarrow \mathrm{Fe}^{++}+2 e
$$

and the cathodic reaction, the rate determining steps in strong acids [30],

$$
H^{+}+e \rightarrow H_{a d s}
$$

followed by:

$$
H_{a d s}+H_{a d s} \rightarrow H_{2}
$$

Fig. 5 reflects the reaction order with respect to iron. From the results of this figure, it could be said that the adsorption of APTT molecules does not influence the anodic reaction order.

The APTT adsorption hinders the cathodic process (Eqs. (7) and (8)) of hydrogen evolution on mild steel (Fig. 1). The rate of this process on mild steel in the electrolytes $(1 \mathrm{M} \mathrm{HCl})$ containing APTT (curve y80) decreases to several times compared to that in the pure electrolyte (curve y0).

Due to adsorptionof the inhibitor molecules, APTT perhaps prevents the adsorption of $\mathrm{H}^{+}$on the surface of the electrode, thereby slowing down the cathodic reaction, i.e., the rate determining steps in strong acids, and consequently slowing down the anodic reaction. This is usually observed by the decrease in the corrosion rate, which depends on the surface coverage [4,30,31]. This is in good agreement with the observed result, as seen in Fig. 4, that the corrosion rate decreases linearly with the coverage $\theta$ by the adsorbate.

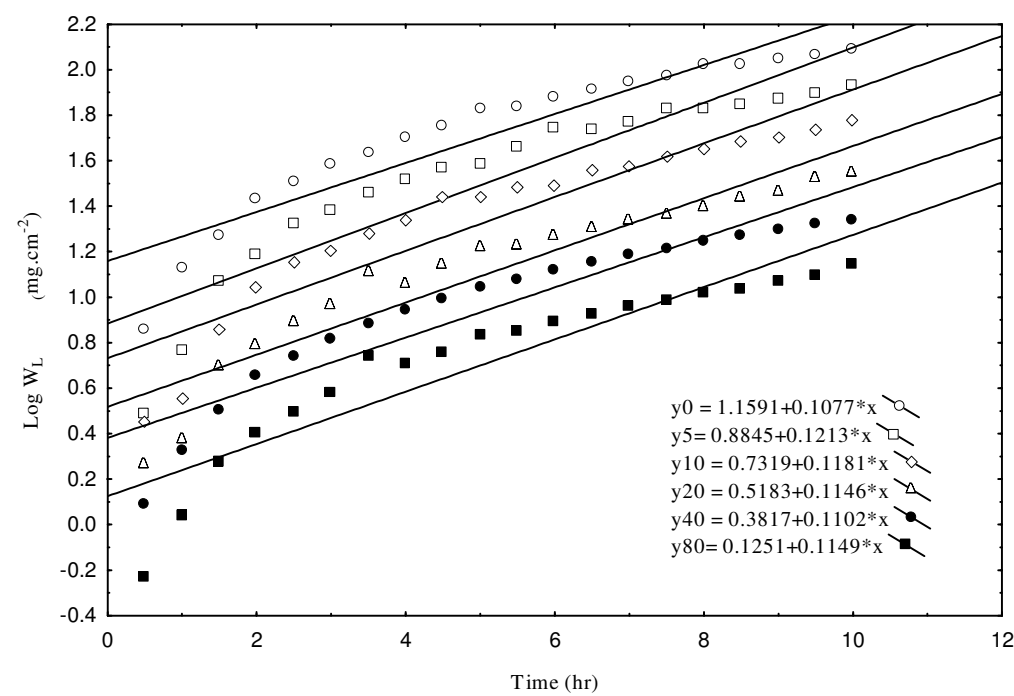

Figure 5. Variation of $\log \mathrm{W}_{\mathrm{L}}$ for mild steel coupons corrosion in $1 \mathrm{M} \mathrm{HCl}$ solution with and without APTT at $30^{\circ} \mathrm{C}$. 
Adsorption models for the adsorption of APTT on mild steel surface in $\mathrm{HCl}$ solution may be proposed on the basis of the experimental results.

In acidic solutions, APTT exists as cationic species $\mathrm{R}^{+}$by being protonated at the sulphur atom, since thiol compounds such as APTT are known to be protonated at the sulphur atom $[32,33]$. The protonated APTT can be adsorbed on the mild steel surface on previously adsorbed chloride ions, since organic compounds with heteroatoms of $\mathrm{N}$ and $\mathrm{S}$ are able to adsorb on the metal surface even at high concentration of chloride ions [34].

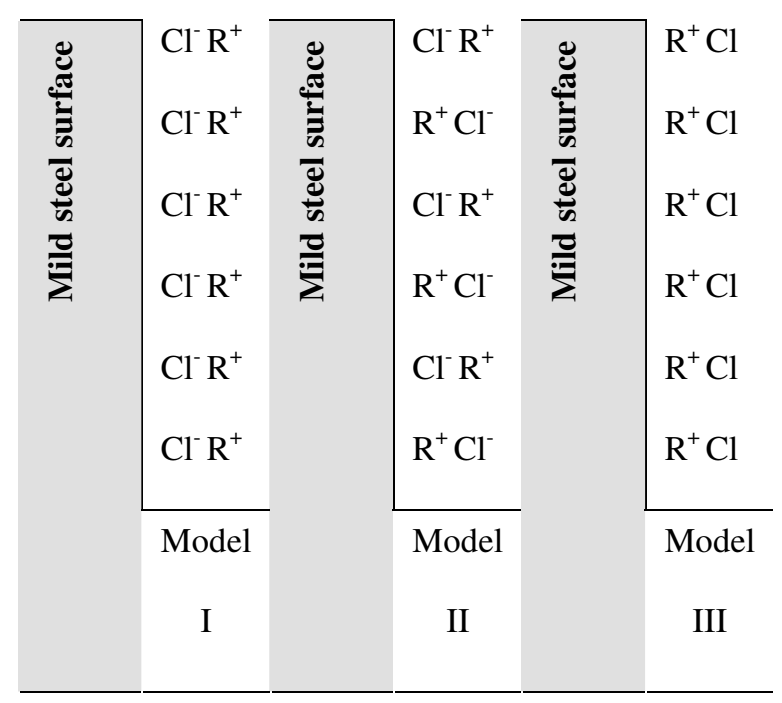

In model $\mathrm{I}$, at low concentrations $\left(5 \times 10^{-5} \mathrm{M}\right)$, APTT cations $\left(\mathrm{R}^{+}\right)$from solution cluster around the chloride ions by columbic attraction on the mild steel surface where chloride ions are already adsorbed, then as a result tend to be weakly bound to the chloride ions, resulting in low coverage $(\approx 0.3)$ of the electrode surface. Abiola [35] proposed a similar model for adsorption of AMMPTC inhibitor and its derivative on mild steel surface in $\mathrm{HCl}$ solution.

Model II represents a situation of weak adsorption of chloride ions; $\mathrm{R}^{+}$at high concentration tends to withdraw the chloride ions on the surface into the solution. Hence, co-adsorption of cations and chloride ions is possible as in model II, on increasing the concentration of APTT from $10 \times 10^{-5}$ to $20 \times 10^{-5} \mathrm{M}$.

The degree of desorption of chloride ions from the surface depends on the degree of adsorption of $\mathrm{R}^{+}$which is a function of the concentration of APTT. When the concentration of APTT is increased to $40 \times 10^{-5}$ and $80 \times 10^{-5} \mathrm{M}$, the chloride ions on the surface provide a better electrostatic condition, which promotes a direct adsorption of cations on the surface through its polar group, as seen in model III.

\section{Conclusion}

The corrosion rate of mild steel in $\mathrm{HCl}$ solution in the presence of APTT decreased with the increase in the surface coverage value, $\theta$. APTT molecules in cationic form adsorb on the mild steel surface through chemisorptions interaction with the mild steel surface. The negative values of free energy of adsorption, 
$\Delta \mathrm{G}_{\text {ads }}^{\mathrm{o}}$, suggest the spontaneous adsorption of APTT on the mild steel. The dependence of $\Delta \mathrm{G}_{\text {ads }}^{\mathrm{o}}$ on surface coverage, $\theta$, is due to the heterogeneous nature of the mild steel surface. APTT adsorbs on mild steel surface in the supporting electrolyte without modifying the kinetics of the corrosion process.

\section{Acknowledgment}

We gratefully acknowledge Universiti Kebangsaan Malaysia for support of this work (Grant No.UKM-GUP-BTT-07-25-170).

\section{References}

1. O. Benali, L. Larabi, B. Tabti and Y. Harek, Anti-Corros. Method Mater. 52 (2005) 280. [10.1108/00035590510615776]

2. A.S. Fouda, A.A. Al-Sarawy and E.E. El-Katori, Desalination 201 (2006) 1. [10.1016/j.desal.2006.03.519]

3. E.A. Noor, Corros. Sci. 47 (2005) 33. [10.1016/j.desal.2006.03.519]

4. O.K. Abiola, N.C. Oforka, Scientia Africana 2 (2003) 82.

5. C. Fiaud, A. Harch, D. Mallouh and M. Tzinmann, Corros. Sci. 35 (1993) 1437. [10.1016/0010-938X(93)90369-R ]

6. F. Chaouket, A. Sghiri, A. Ben Bachir and A. Frignani: Proc. $8^{\text {th }}$ Eur. Symp. on Corrosion inhibitors, Ferrara, Italy, September 1995, University of Ferrara, 1031.

7. N.A. Rogozhnikov, R.Y. Bek, Adsorption of Cyanide Ions on Gold, Russ. J. Electrochem. 32 (1996) 1333.

8. A.S. Fouda, H.A. Mostarfa, F. El-Taib, G.Y. Elewady, Corros. Sci. 47 (2005) 1988. [10.1016/j.corsci.2004.09.008]

9. B.B. Damaskin, A.N. Frumkin, Adsorption of molecules on electrodes, in: N.S. Hush (Ed.), Reactions of Molecules at Electrodes, Wiley-Interscience, London, 1971, p. 1.

10. E.A. Tumanova, A.Y. Safronov, Russ. J. Electrochem. 34 (1998) 153.

11. H. Baeza, M. Guzman, P. Ortega, L. Vera, J. Chil. Chem. Soc. 48 (2003) 23. [10.4067/S0717-97072003000300004]

12. O.K. Abiola, N.C. Oforka, Mater. Chem. Phys. 83 (2004) 315. [10.1016/j.matchemphys.2003.10.001]

13. M. Langrene'e, B. Mernari, M. Bouanis, M. Traisnel, F. Bertiss, Corros. Sci. 44 (2002) 573. [10.1016/S0010-938X(01)00075-0]

14. S.S. Abd ElRehim, H.H. Hassan, M.A. Amin, Corros. Sci. 46 (2004) 5. [10.1016/S0010-938X(03)00133-1]

15. L.G. Qiu, A.-J. Xie, Y.-H. Shen, Corros. Sci. 47 (2005) 273. [10.1016/j.corsci.2004.05.009]

16. S. Ramesh, S. Rajeswari, Corros. Sci. 47 (2005) 151. [10.1016/j.corsci.2004.05.013]

17. M. Abdallah, E.A. Helal, A.S. Fouda, Corros. Sci. 48 (2006) 1639. [10.1016/j.corsci.2005.06.020] 
18. T. Zhao, G. Mu, Corros. Sci. 41 (1999) 1937. [10.1016/S0010938X(99)00029-3]

19. S.S. Abd El-Rehim, H.H. Hassan, M.A. Amin, Chem. Phys. 70 (2001) 64. [10.1016/S0254-0584(00)00468-5]

20. S.S. Abd El-Rehim, H.H. Hassan, M.A. Amin, Mater. Chem. Phys. 78 (2003) 337. [10.1016/S0254-0584(01)00602-2]

21. Y. Harek, L. Larabi, Kem. Ind. 53 (2004) 55.

22. S. Muralidharan, R. Chandrasekar, S.V.K. Iyer, Proc. Indian Acad. Sci. 112 (2000) 127.

23. J.O'.M. Bockris, A.K.N. Reddy, Modern Electrochemistry, vol. 2, MacDonald Ltd., London, 1970, p. 772.

24. H.B. Rudresh, S.M. Mayanna, J. Electrochem. Soc. 124 (1977) 340. [10.1149/1.2133301]

25. B.B. Damaskin, A.N. Frumkin, Adsorption of molecules on electrodes, in: N.S. Hush (Ed.), Reactions of Molecules at Electrodes, Willey-Interscience, London, 1971, p. 36.

26. M. Suzuki, Adsorption Engineering, Elsevier, Amsterdam, 1990.

27. S.A.Umoren, E.E. Ebenso, Mater. Chem. Phys. 106 (2007) 393. [10.1016/j.matchemphys.2007.06.018]

28. S.A. Umoren, I.B. Obot, E.E. Ebenso, E-journal Chem. 5 (2) (2008) 355.

29. W.W. Damaskin, O.A. Pietrij and W.W. Batrakow, Adsorption of Organic Compounds on Electrode, Plenum Press, New York (1971).

30. O.K. Abiola, N.C. Oforka, J. Corros. Sci. Technol. 2 (2004) 116.

31. B.G. Ateya, B.F. El-Andoni, F.M.A. El-Nizamy, Bull. Chem. Soc. Jpn. 54 (1981) 3157. [10.1246/bcsj.54.3157]

32. O.K. Abiola, N.C. Oforka, S.S. Angaye, Mater. Lett. 58 (2004) 3461. [10.1016/j.matlet.2004.06.043]

33. M.S. Abdel aal, A.A.A. Wahab, A. El Saied, Corrosion 37 (1981) 557.

34. E.E. Ebenso, Mater. Chem. Phys. 79 (2003) 58. [10.1016/S02540584(02)00446-7]

35. O.K. Abiola, Corros. Sci. 48 (2006) 3078. [10.1016/j.corsci.2005.12.001] 